\title{
Needs Analysis as a Prerequisite for Designing an ESP Course for Medical Students
}

\author{
Hussein Hassan Ibrahim \\ Department of English Language, Faculty of Arts, University of Sinnar, Sinnar, Sudan \\ Email: Karkad1967@hotmail.com
}

How to cite this paper: Ibrahim, H. H. (2020). Needs Analysis as a Prerequisite for Designing an ESP Course for Medical Students. Open Journal of Modern Linguistics, 10, 83-103.

https://doi.org/10.4236/ojml.2020.102006

Received: December 29, 2019

Accepted: April 7, 2020

Published: April 10, 2020

Copyright ( $\odot 2020$ by author(s) and Scientific Research Publishing Inc. This work is licensed under the Creative Commons Attribution International License (CC BY 4.0).

http://creativecommons.org/licenses/by/4.0/

\section{(c) (i) Open Access}

\begin{abstract}
This study aims to assess the medical students' needs analysis at the Faculty of Medicine at Al-Neelain University in the field of English for Specific Purposes (ESP). It also aims to examine the perceptions of the students and their instructors about the present syllabus and the challenges, which the students and the instructors face. It is an exploratory study, that is, to discover the aspects of reviewing a program by involving both instructors and students to express their views. The researcher followed the descriptive and analytical approach. The subjects of this study were of two types: the instructors who are either having experience in teaching ESP syllabus or teaching the current program (i.e. English for Medical Purposes) and medical students of first and second year. The number of the respondents who participated in the study was five instructors, twenty-five students of the first year and twenty-five students of the second year. The data, which were collected by the two forms of the questionnaires, were analyzed through statistics (numbers) then converted into the forms of percentage. The findings of this study confirmed that there were several problems that the students faced at the faculty such as the lack of some of the basic skills, especially speaking and listening skills. As recommendation plays an important basis to undergo some changes within the current syllabus, it is recommended to review the current syllabus to undergo some changes in the content of the syllabus so as to meet if not all, most of students' needs towards their medical study. It is also recommended to use different methods for collecting data such interviews and classroom observation to get more productive data as well as to use more technical aids such as computer, videos and TV.
\end{abstract}

\section{Keywords}

ESP, Needs Analysis, Prerequisite, Design, Course 


\section{Introduction}

Recent years have witnessed a practical movement in the area of English for Specific Purposes (ESP) despite the fact that there were not enough studies that had been conducted in this area. As such, the interest in the field of adult education has been growing. This growth has resulted in establishing a lot of polytechnics and vocational institutions that have been established to meet the students' needs (Sudan and Malaysia as two examples). Due to the recent invading nature of globalization in the specific area of ESP programs, that is, vocational-technical education and human resources development, a special attention has been given to the following aspects:

"the purpose of education in the 21th century; learning for the workplace; national culture and technological advances; the globalization of education; education and quality control; and future challenges for educational institutions." (Styler, 1986: p. 289)

There has been a widespread demand for English as a means of communication. Therefore, both instructors and learners are strongly committed to teaching and learning the English language. In addition, the users of English understand that English has a role in a wide range of perceptions, business, and enterprise (Kachru, 1986). Accordingly, the idea to design special programs has been made to meet the learners' needs, that is, English for Specific Purposes (ESP). It regained its importance as a part of English Language Teaching (ELT), which needs to be well designed to see whether its goals and objectives have been achieved or not (Hutchinson \& Waters, 1987). Any language-teaching program has certain concepts and criteria, but in ESP, these concepts and criteria are to be much focused on and with specified goals. Therefore, ESP sponsors consider learners are investors in the ESP programs that have been established and they want to gain the outcomes of their investment. As such, there have been a growing number of individuals who need languages for occupational and vocational purposes as well as for general educational purposes. This trend has led to a corresponding increase in the attention of the programs for study in order to provide appropriate teaching criteria. Thus, ESP is about content-based instruction in a variety of field such as medicine, business, chemistry, information technology, computer science, engineering, etc. There are two obvious categories of ESP, that is, English for Occupational Purposes (EOP) and English for Academic Purposes (EAP). EOP is concerned with "the preparations for professional occupations that students are likely to go into when they graduate" (Flowerdew \& Peacock, 2001: p. 11). EAP in contrast, relates to the study purpose (Dudley-Evans \& St. John, 1998). This type of aspect is taught generally to students who need to perform it for their academic purposes in educational institutions. The type of language is usually based on a special discipline in higher levels of education when the student specializes (in-study) or plans to specialize (pre-study) as stated by Kennedy and Bolitho (1990). The basis of ESP, containing EAP is "the specif- 
ic needs of its learners/clients" (Dudley-Evans \& St. John, 1998). All the decisions as to content and method of teaching are based on why the students need to learn. This trend leads to what is called needs analysis. A needs analysis is essential for any instructor who intends to know the purpose of the students for language learning. Therefore, this tendency allows the instructor to collect and analyze information in order to identify and validate the language. Thus, this concept will guide to build up an English language course to accomplish the specific needs of the learners.

Nowadays, there is an increasing number of English language programs, which have been constructed whether in private institutions or at the tertiary levels. As a result, they adopted ESP approach in their established courses (see Figure 1). The intended role for these courses is to equip learners with English language knowledge that helps them in both study and workplace. Therefore, the lack of English language proficiency among many learners marks as an obstacle for job seekers. To this extent, many institutions have followed a systematic method to provide learners from different fields of study with ESP programs to help them carry out future jobs successfully. Accordingly, ESP practitioners and educators are looking for the applications of ESP approach in order to use them in various English language programs that have been designed for different areas of specialization. Instructors set up ESP programs for English language courses by producing and developing materials from commercial texts for teaching English for special purposes accompanied by the materials, which are designed for teaching English for general use or gathering various materials in the forms of handouts. As a result, there is a wide gap between the language which the students acquired and the language they really require. It is the gap that project work can solve (Fried-Booth, 1986). Any project work should give the ESP learners opportunities for language use and development. A useful program makes the language-learning task seem more manageable. The program is now seen as an instrument with which the instructor can achieve a degree of congruence between

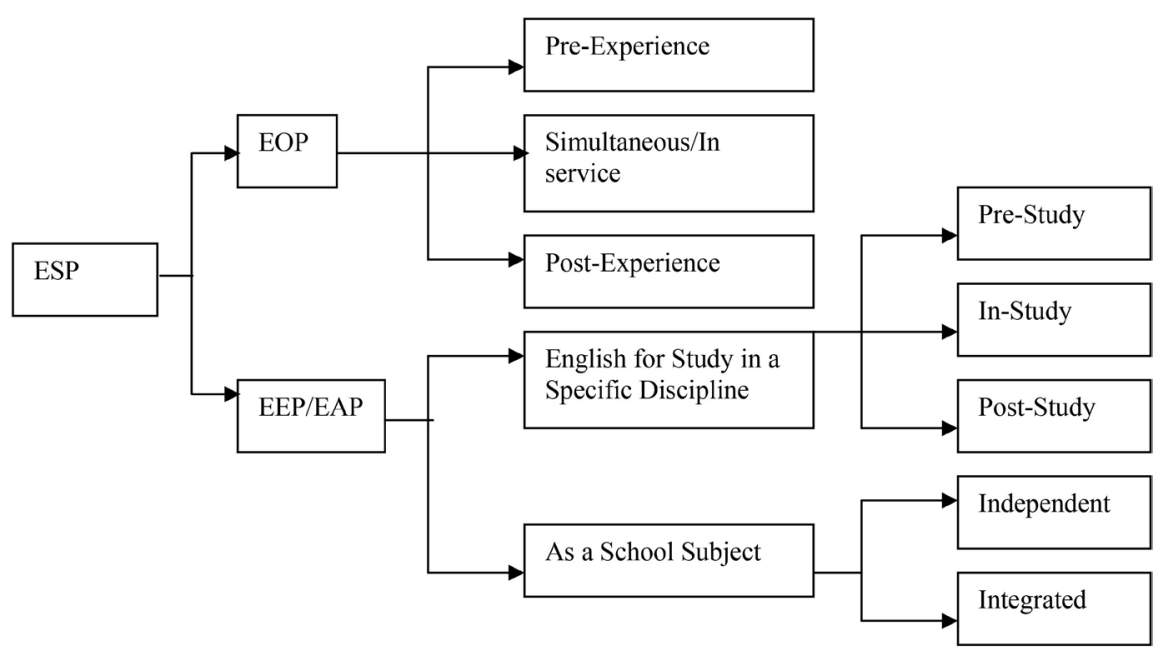

Figure 1. The classification of ESP by experience. 
the needs and aims of the learner and the activities, which will take place in the classroom (Yalden, 1984). Candlin and Murphy (1987) stated that:

"task-based learning continues and develops recent attention to learner-centred approaches, and in particular the ideas of differentiation and learner interdependence" (p. 3), adding that "tasks serve as compelling and appropriate means for realizing certain characteristic principles of communicative language teaching and learning." (p. 5)

\subsection{Subjects}

The subjects consist of two groups: the students who take English for Medical Purposes (EMP) and the instructors who teach the current syllabus. Referring to these types of students, Celani et al. (1988), and Sharp (1990) stated that it is more successful to involve both instructors and their students in building up the syllabus, stressing their views and perceptions about syllabus design and within their needs.

\subsection{Instruments}

The researcher used two forms of questionnaires for conducting a needs analysis, namely, the student's questionnaire and the instructor's questionnaire. This method of gathering data is frequently used because it saves time and yields quick results. A number of questionnaires, which were distributed: instructors (5 copies), first year students ( 25 copies), and second year students ( 25 copies). The method of the questionnaire distribution followed was both self-administered and group administered. The advantage of these two methods is to assess and receive accurate answers from the respondents in a short time. Most of the items of the questionnaire were taken from a combination of items developed by Schleppegrell and Royster (1990) and Yoo (2000).

\subsection{Data Analysis Technique}

After collecting the data, the researcher used frequency counts and percentages for questionnaire results. The use of tables and figures is considered as an effective way to analyze the data obtained.

\section{Review of Literature}

\subsection{How Do Specialists Know If Their Institutions Need an ESP for Their Departments?}

The question above turns the study to the department specialists who administer ESP programs, which are taught as a demand of the current situation for adults to learn ESP according to their areas of specialists such as business, medicine, science, etc. These specialists may wish to focus on their program that uses English with the program's epistemology (theory of knowledge), by using an ESP model. Firstly, the specialists will need to form a needs analysis to determine if an ESP model is necessary. Secondly, to find out what difficulties the program 
may have in adapting to an ESP model. Finally, to address the necessary changes needed to migrate towards an ESP model because a needs analysis becomes a renewal demand towards English language learning. This part reviews theoretical foundations significant to ESP, conducted by a number of researchers with a special attention to the role that a needs analysis plays in the development of material for English language programs. For instance, English for Medicine. Accordingly, a needs analysis is based on the analysis of learner's reasons for learning English, which in turns, will eventually lead to the construction of an English language course to fulfill the specific needs of the learners.

\subsection{An Overview of English for Specific Purposes}

English for Specific Purposes (ESP) is a systematic way of teaching that focuses on the learner as a target of study. It has a great contribution, which concerns teaching of English for Specific Purposes. Its importance came to be seen as it emphasizes the intensive analysis of the learners' needs towards course design. This focus of analysis incorporates careful assessment of skills that the learners have and to what extent they lack in their target language situation for considering what steps should be taken to provide them with certain knowledge. The awareness of both General English (GE) and English for Medical Purposes (EMP) mark a crucial step towards their advancement and improvement whether in study or future jobs. In general, learners' needs analysis depicts that they have to be trained with a special type of language, which contains vocabulary, specific grammatical structures, phrases, styles and principles of communication which relate to future medical careers. In turn, the collected data from needs analysis can be used as a precision of the intended goals that lead to execution of the language programme. These goals, afterwards, can be stated as specific teaching objectives, which in turn will function as the base on which to develop lesson plans, materials, tests, assignments and activities. In fact, a needs analysis will help determine the rationale for the teaching programme (Hutchinson \& Waters, 1987).

The rapid expansions in the areas of science, technology and economic activities in the world have led to the increased need for English as a means of communication. To this extent, English has become a reciprocal language of communication worldwide especially when we have to access the field of science and technology as it seems difficult to do so in the absence of English language. The increasing need for English language has caused changes in English language teaching (ELT) especially in the last few decades, which requires a new look at one aspect of English Language Teaching, which is English for Specific Purposes (ESP). This is because ESP is about the training of students in specialized language areas such as law, economics, physics, medicine or food preparation.

\subsection{The Origin of ESP}

The origin of ESP marks a significant point in the history of English Language 
Teaching (ELT). There were three main features, which led to the emergence of ESP: the Demands of a Brave New World, a Revolution in Linguistics, and a New Focus on the Learner in Language Teaching (Hutchinson \& Waters, 1987).

As stated by Hutchinson and Waters (1987), there were two key historical periods in the emergence of ESP. The first period began after the Second World War (SWW). The post-war period witnessed a broad development in “... scientific, technical and economic activity on an international scale" (p. 1). These developments created a united and controlled world by two important forces, that is, Technology and Commerce. These two central forces carried a need for a cohesive world language to be used as a reciprocal tool between people. This nature created English as a dominant language among nations. As a result, there was a huge rush forward in the number of people throughout the world seeking to learn English in order to communicate in the growing economic system. As such, learning English language became the first step to participating effectively in the fields of commerce and technology. For example, a businessperson who wishes to find a wider market for his goods. Similarly, an air traffic controller who needs to understand and give instructions to international flight crews, and doctor who wants to keep up with the latest medical breakthroughs and techniques. Seen from this view, the need for English became a matter of crucial demand for mutual understanding.

The Oil Crisis of the early 1970s marked the beginning of the second period. It led to a huge increase of Western expertise and knowledge flowing into the oil-rich countries especially in the South East and South America. The rush of interest in learning English that arose from these developments had a significant effect on the English teaching and learning.

The second key factor was a revolution in linguistics. Traditional linguists set out only to describe the features of language in the form of generated rules to govern language production. However, the revolutionary pioneers in linguistics paid greater attention to the ways in which language was used in real world communication (i.e. its communicative functions). Upon that period, different names were given to different varieties of English such as American English, British English and Black English based on the different extent of dialects and accents. Hence, in the late 1960s and the early 1970s there were many attempts to describe English for Science and Technology (EST).

The final key factor focused on the method by which teachers deliver the language. More attention was given to the ways in which learners acquire language and the differences in the ways language is acquired. It was found that learners apply different learning strategies, use different skills, enter the language-learning situation with different learning schemata, and are motivated by different needs and interests. The idea of designing specific courses to meet the learners' individual needs was a natural extension of this thinking. In turn, the use of needs analysis to identify these needs became an integral element of ESP. For that reason, the focus was given to learner-centeredness or a learning-centered approach. 


\subsection{The Growth of ESP}

By the advent of the early 1960's, ESP has become one of the most important areas of English as a Foreign Language (EFL) teaching. Its emergence has resulted in the increasing number of educational institutions that offer programmes to cover a range of ESP courses for overseas students in English speaking countries. Because of this expansion of the ESP programmes, there are now a number of famous international journals. They contributed a lot to the area of ESP such as "English for Specific Purposes: An international journal", ESP Asia, ESP World, The Asian ESP Journal, and the ESP SIG groups of the International Association of Teachers of English as a Foreign Language (IATEFL) and Teaching English to Speakers of Other Languages (TESOL). These types of journals contributed a lot in national and international conferences and seminars. It is notable to name some examples for this important growth of ESP, that is, Japan as an example. In this country, the progress of ESP has been initiated to be "slow" but the distinct expansion to happen over the recent "few years" (Japanese Ministry of Education's decision in 1994). The decision of the Japanese Ministry of Education was to increase the attention of ESP syllabuses and hence the Japanese universities have been given the responsibility of constructing ESP courses. This development of confidence has "led to a rapid growth in English courses aimed at specific disciplines", e.g. "English for Chemists", to replace the more conventional "General English" courses. Consequently, the community of ESP in Japan as an example has been well recognized by the Japan Association of College English Teachers (JACET), which was established in 1996.

\subsection{Benefits of ESP}

It is known that ESP programs aim to develop linguistic skills, which relate to the special fields of activity. Wright (1992: p. 68) explains that the "nature" of the linguistic items and the "ways" in which they are presented and "how" they are experienced, are considered extremely important. He ascertains that ESP benefits are stressed in three forms as follows:

Firstly, there is learning speed. ESP results in faster acquisition of required linguistic items. This is because it follows the pattern of native speaker acquisition of language for specific purposes, in which speakers learn in authentic, content-based contexts. ESP not only follows this pattern, but also provides an opportunity to learn in an accelerated, intensive context.

Secondly, there is learning efficiency. On an ESP, course trainees make the maximal use of their learning resources, all of which are brought to bear on acquiring specific, pre-identified linguistic items and skills. Obviously, the needs analysis is of vital importance here, since it enables trainers to determine the specific requirements of trainees.

Thirdly, there is learning effectiveness. On completion of an ESP course, trainees are ready to use language appropriately and correctly in job-related tasks, tasks that have been identified prior to the course by means of a needs 
analysis. Therefore, upon completion of the course, English is usable immediately in the employment context (Wright, 1992: p. 68). Dudley-Evans and St. John (1998) sum up the advantages of ESP in the following four points:

1) Being focused on the learner's need, it wastes no time;

2) It is relevant to the learner;

3) It is successful in imparting learning; and

4) It is more cost-effective than "General English".

\section{Needs Analysis}

Needs Analysis (NA) is a term, which marks a major step for designing a target course/programme. It includes all the activities used to collect information about the students' learning needs, wants, wishes, desires, etc. The process also sometimes involves looking at the expectations and requirements that the other interested parties need such as instructors, administrators, financial supporters, and other people who may be influenced by the programme such as students' family members or employers. It can be very formal, extensive and time consuming, or it can be informal, narrowly focused and quick. Some of the resources for conducting a needs analysis may include surveys and questionnaires, test scores, and interviews. Thus, the process with an analysis of a target group of students may be as for some teachers who never pay attention to learners' interests and ignore students as a source of essential information. Many studies have been carried out on learner needs, for example, classifying assignments; observing students in natural settings; description of discourse and classroom behavior; and surveying students' backgrounds and goals (Horowitz, 1986). Thus, the ESP needs analysis is considered as the major step that is followed prior to syllabus design. It decides whether the syllabus meets the requirements that have been assigned to its existence or not. To illustrate this issue, the ESP learners are to be tested against the programme that has been designed to meet their learning needs in terms of their performance in real-life situations, that is, acquiring the language items; the directed skills; and the influences of ESP on their abilities and how to deal with the obstacles that stand in the way. As a result, ESP has added a lot to language teaching and therefore, has its huge emphasis on careful and extensive needs analysis for course design (Johns, 1991). Thus, a number of pioneer writers in the field of ESP have focused a lot on its diverse types particularly after the Second World War. The idea came into existence to find a language that could be considered as a reciprocal contact. As such, this aspect made its way through English language as an international means of communication among nations.

In the beginning, the ESP specialists have developed their style to design programs with great focus on needs analysis as it is the backbone for manipulating programmes, which require much thoughtfulness to take action. To this extent, many methods of teaching were taken as a step to gather information. For example, audio and video, classroom observation, interview, questionnaire, and 
case study. These methods of collecting data give us an idea about how following certain and specific methodology guides to invaluable results and findings that may be important for future studies.

\subsection{The Emergence of Needs Analysis}

The year 1920 witnessed the first emergence of needs analysis, which was produced by Michael West in India. Since then the concept of needs analysis has been developed and introduced into English language teaching (ELT) while the growth of science and technology and the interest for developing ESP programmes have taken place in the world. The concept was taken up eagerly in the 1970s by the Council of Europe, which was coincident with the spread of ESP (Munby, 1978). By the 1990s, in many countries, needs analysis appeared in language teaching. Today, it is widely believed that needs analysis is a prerequisite to the specification of any language programme objectives. On the contrary, Richterich (1983) argues the concept of language needs has always been blurred and needs to be clarified. Overall, different conceptions of needs analysis exist and each approaches the concept from a different point of view. Berwick (1989) suggests providing an operational definition of needs for each situation because its elements change in accordance with the ideas of the evaluator or prominent features of an educational system. Similarly, Dudley-Evans and St. John (1998), too, hold that needs have been defined using a puzzling plethora of terms. For example, outsiders from facts obtain objective and perceived needs while subjective and felt needs are derived from insiders and match with cognitive and affective factors. Likewise, product-oriented needs are derived from the goal or target situation and process-oriented needs are derived from the learning situation. Today's concept of needs analysis, however, includes aspects of all these approaches and a variety of actions that can be done in conducting needs analysis to achieve information from the gathered data. Lytle (1988) considers the assessment of learners is considered as a fundamental element of any educational program that can be useful for both teachers and learners.

\subsection{The Concept of Needs Analysis}

The concept of needs analysis and definition introduced by Graves (1996) who says needs analysis involves finding out what the learners know and can do what they need to learn or to what extent the course can bridge the gap. Following the above interpretation concerning needs analysis, it can be noted that needs analysis involves searching and interpreting information about learners' needs so that the course will address them effectively. However, an identification of needs analysis maybe so difficult to conduct due to the different nature of learners, that is, different learners have different types of needs.

Needs analysis can be divided into two types: subjective needs and objective needs. Brindley (1989: p. 70) defines objective needs as "derivable from different kinds of factual information about learners, their use of language in real-life 
communication situation ..." and subjective needs as "derivable from information about affective and cognitive factors such as personality, confidence, attitudes, learners' wants and expectations ..." For Brindley's (1989) conception and definition of needs, the researcher notices that there are similarities as well as dissimilarities between the two types of needs (i.e. subjective and objective needs). It is clear to note that, the information about needs can be obtained from several people who are related to the course. In this respect, it is viewed that in Malaysian context, needs analysis is not always carried out when writing up some ESP courses. Accordingly, Brindley (1989) reports that, to meet the demand of clients in private organizations to train their personnel, some ESP practitioners have produced many adhoc courses without a thorough needs analysis being carried out. The introduction of new commercial English courses in Malaysian polytechnics in 1995 has uncovered the screen that the old English courses lacked the study of proper needs analysis.

Needs analysis can be defined as the identification of difficulties and standard situations by observation of participants functioning in a target situation by the use of interviews and questionnaires as well as classroom observation. The overall aim of the NA is the identification of elements, which will provide themselves to training. Language needs analyses are used where the learners in the selecting situations face very similar difficulties. Richterich and Chancerell (1980) argue that the aim is not only to identify elements but also to establish their relative importance, to find out what is crucial, necessary, or merely desirable. West (1994) states that NA is essentially a pragmatic activity focused on specific situations, although grounded in general theories, such as the nature of language and curriculum.

\subsection{Steps for Conducting Needs Analysis}

Hutchinson and Waters (1987) stated the following steps to conduct a Needs Analysis (NA) and to develop materials:

1) An observation of a real course taught (University of Sharjah). The course took about three months. They planned to visit this class to discover and predict the English language linguistic skills for nursing students have and to find out the linguistic pre-requisites they need in order to be able to deal with the content and language that are components of such an English for Medical Purposes (EMP) course. They also planned to take field notes and try to videotape one class if possible.

2) Conducting an informal interview with a course teacher who would normally be one of my colleagues to discuss the students' strengths and weaknesses, the materials, and the assessment procedures.

3) Preparing a questionnaire as an instrument to obtain enough information about the students' needs and goals: linguistic and professional. The questionnaire was handed to an estimated 15 students (this is the typical ESP class size at the workplace). 
4) Preparing an A level-evaluation English test as the next instrument. The students supposed to pass their foundation year program achieving an overall band 5 in IELTS, but the aim of my placement test was to double-check the students' level in English and find out if the class would be to some extent a multi-level one. The test would include items examining the students' grammatical knowledge, reading comprehension, writing as well as to check the students' speaking by interviewing them.

5) Analyzing the data obtained and employed it to write the course objectives and a syllabus. So, the NA information would help them choose appropriate teaching methods, materials, and assessment. There were also other factors included in the NA process including administrative technicalities of the course.

6) Practicing teaching the course at the college campus, so they were aware of the logistic and institutional requirements of the course delivery such as classroom size, IT supplementary materials, and timing. They were also familiar with the students who move from the university foundation year into their majors; this helped them to be more knowledgeable with the cultural background of the students.

Hutchinson and Waters (1993) suggest that learner's needs should be taken into consideration when the process of planning the content of a language programme is taking place. "All language teaching must be designed for the specific learning and language use purposes of identified groups of students" (Johns, 1991: p. 67). Richterich (1983: p. 2) states that it is difficult to reach an agreed definition of needs analysis in that "The very concept of language needs has never been clearly defined and remains at best ambiguous". The concept of needs analysis can only be understood through the various perspectives and proposed various interpretations.

Research carried out in the field of ESP to date, especially needs analysis, illustrates the significance of needs analysis for developing a course, writing textbooks or course books, and the type of teaching and learning programme that takes place (Robinson, 1991; Jordan, 1997). In this regard, a needs analysis should be carried out during the life of each course; that is, as a system of assessing during the course (Richterich \& Chancerel, 1987). Robinson (1991: p. 15) quote that, "as students become more involved with the course, their attitudes and approach may change". Therefore, identification and analysis of needs should be a continuous process (Richterich \& Chancerel, 1987; Knox, 1986). This can assist both administrators and teachers to introduce changes or modifications, if considered necessary; in order to help or promote learners in their steps forward throughout the prescribed programme, and accordingly needs analysis can provide input to educational policy-makers (White, 1988).

\subsection{Types of Needs}

Hutchinson and Waters (1987) state that learner's needs should be considered as 
the key factor in the process of preparation the content of a language programme. The related research presents a range of divisions on needs, which come out to be complementary: perceived (prescribed)-felt needs (Robinson, 1991), objective-subjective needs (Brindley, 1989 quoted in Robinson, 1991), and target learning needs (Hutchinson \& Waters, 1987). Robinson (1991) reflects on all accurate information about the learner-language proficiency, language difficulties, and use of language in real life situation to form objective needs. However, cognitive and affective needs of the learner in language learning such as confidence, feelings, and expectation are considered to form subjective needs. Hutchinson and Waters (1987: p. 54) define target needs as the ones that 'the learner needs to do in the target situation', these are necessities, lacks, and wants, and "what the learner needs to do in order to learn" are his learning needs.

\subsection{The Importance of Implementing a Needs Analysis}

There is no doubt that the learners and teachers may have different needs. Robinson (1991) considers that needs analysts should pay more attention when they intend to collect information from a variety of sources due to the multiplicity of the views on prerequisites for an ESP course. Up to this point, the researches done in the area of ESP give emphasis to the importance of a needs analysis for designing a programme, writing textbooks or course books, and the type of teaching and learning that takes place (Robinson, 1991; Jordan, 1997). A needs analysis attempts to find answers to the questions, which starts with: who, what, when, and where but not how, that is, the target learners (who needs to be trained), the task or content (what needs to be taught) and the context or training environment (where and when the training needs to be conducted). Following the increasing demands for dependability and importance of ESP, Long (2005) mentions four reasons for carrying out a needs analysis:

Firstly, to determine the relevance of the material to the learners' situations;

Secondly, to justify the material in terms of relevance for all parties concerned (teacher, learner, administration, parents);

Thirdly, to account for differences in learner needs and styles;

Fourthly, to create a syllabus, which will meet the needs of the learners as fully as possible within the context of the situation.

\subsection{Approaches to Needs Analysis}

In order to conduct a precise needs analysis, it should engage Present Situation Analysis (PSA) and Target Situation Analysis (TSA). PSA aims at realizing the students' English proficiency level and their accessible language requirements at the start of a language programme. However, learners' language requirements concerning the target situation are recognized through TSA (Robinson, 1991: pp. 8-9). Robinson (1991) also states that TSA and PSA are complementary and produce a needs analysis. On the other hand, Jordan (1997) suggests a trichoto- 
my of needs analysis as follows: Deficiency Analysis (DA), Strategy Analysis (SA), and Means Analysis (MA): deficiency analysis concerns with what the learner lacks (necessities); strategy analysis looks at the learners' preferences in terms of learning styles and strategies, or teaching methods; means analysis examines the "constraints"-local situation-to realize the ways, which leads to performance of a language programme.

In a study followed by Johns (1981) in which he applied an academic skill questionnaire. The selection was made randomly for a number of 200 faculties from all departments to find out which skills were most important to non-native speaker success in university classes. The participants firstly have graded the receptive skills. More to the point, all except the engineering students graded general English above Specific English.

In another study, Ostler (1980) assessed the students' perceptions of necessary academic skills. The results exposed that there is an obvious dissimilarity between the academic skills required by graduate and undergraduate students. As such, needs analysis gives an idea about the influence and the performance of an effective teaching/learning procedure. It has contributed a lot to recent successful course design compared to the earlier one, which is designed in the absence of learners' involvement. As a result, there is a significant difference between the earlier and the recent models. Needs analysis starts with EAP, but in the form of broader attitude. However, the learners should be given help to use English efficiently in classroom situations and hence EAP courses should be designed effectively to equip them with the necessary skills. In this regard, Jordan (1997) has mentioned that the students are expected to do some language activities such as reading journal papers and books; listening to lectures and talks; participating in seminars, tutorials and discussions; writing essays, reports, projects, case studies, dissertations, and theses.

\section{The Status of ESP Today}

The main concerns of ESP have always been and remain with needs analysis, text analysis, and preparing learners to communicate effectively in the tasks prescribed by their study or work situation. It is often said that ESP lacks an underlying theory. It is believed that a theory of ESP could be outlined based on either the specific nature of the texts that learners require knowledge of, or based on the needs-related nature of the teaching.

For much of its early life, ESP was dominated by the teaching of English for Academic Purposes (EAP); most of the materials produced, the course descriptions written and the research carried out were in the area of EAP. English for Occupational Purposes (EOP) played an important but smaller role. In recent years, however, the massive expansion of international business had led to a huge growth in the area of English for Business Purposes (EBP). ESP is part of a more general movement of teaching Language for Specific Purposes (LSP). LSP has focused on the teaching of languages such as French and German for Specif- 
ic Purposes, as well as English. On one hand, as in EAP, EST represents the essential part of which EMP and ELP are categorized. On the other hand, EOP includes English for professional purposes in administration, medicine, law and business, and vocational purposes for non-professional purposes in work or pre-work situations. One may notice a little confusion between EMP as part of EAP and EMP as part of EOP. The former refers to medical students while the latter refers to doctor training (practicing).

EVP can be branched to two categories: Vocational English, which studies the language in terms of training for particular trades or occupations, and pre-vocational English, which is considered as the way of finding a job and doing interviews.

\section{The Future of ESP}

Nowadays, English plays an important role as a means of communication throughout the world, even for native speakers. Therefore, it has become the world-wide dominant language (i.e. the language of science and technology). For that reason, the place of English among other languages has broadly influenced the sort of ESP programmes to be followed, and even the sort of research, which is needed to give lots of emphasis.

A paper presented has illustrated this concern. He looks at the ESP programmes at Sudanese Universities as follows:

“... Although, ESP in Sudanese universities is in its infancy, it has a promising future. No doubt, EFL teachers who teach the ESP courses are more aware of the new progress of the theory and methodology in the field of ESP and its role in the community it serves. This progress in theory and methodology covered three aspects of ESP: genre analysis, corpus analysis and systemic functional linguistics. EFL teachers who teach ESP courses have to distinguish between ESP and..."

Today, the entire world witnesses invading scenery of the flow of information and technologies. Accordingly, there were many sets come into view to send and receive information. One of these devices is computer. If it is connected to the network, it will help us learn the target language and other systematic issues within many ways of delivery.

"Computer is the corner stone of these technologies; via this smart machine we listen, speak, read, write and even communicate at distance. Therefore, it is applicable to invest these facilities in the teaching and learning process. Now, we can change our traditional classes to more modern styles ..."

As discussed above, it is clear that ESP programs depend mainly on the way to teach and how to invest. Data show resemble as key methods to communicate ideas and spread them in the form of constant information. Whereas, in recent years, social media reflects as a methodology through which ESP courses are 
covered and taught.

\section{Findings and Data Analysis}

The findings of this study revealed lots of important information. The following tables show the data analyzed.

Key of Abbreviations:

FYS = First Year Students;

SYS $=$ Second Year Students;

IS = Instructors;

$\mathrm{N}=$ Total Number;

$\mathrm{D}=$ Disagree;

NS = Not sure;

A $=$ Agree.

Item (6) (Table 1) clarifies that "the current syllabus items and topics are related to the students' needs" as have been assigned by all the instructors (100\%) to mean that they disagree. In contrast, the FYS has remarked different responses; twenty of them answered with "Disagree" to the concept with the percentage of $80 \%$, only one responded with "Not sure" with the percentage of $4 \%$ and a number of four students with the percentage of $16 \%$ who were in favor of the concept "Agree". Their counterparts also gave different responses as 15 students of SYS assigned with the statement "Disagree" amounting to the ratio of $60 \%$, three students stated "Not sure" marking the percentage of $12 \%$ and seven students with the percentage of $28 \%$ were in favor of the concept "Agree". As noticed, the greater part of students marked the statement "Disagree" with the percentage of $80 \%, 60 \%$ for FYS and SYS respectively. This view pointed out that the current syllabus items and topics are not related to the students' needs' as assigned by the majority of the respondents.

Table 1. Analysis of students' needs.

\begin{tabular}{ccccccccccc}
\hline \multirow{2}{*}{ Items } & \multicolumn{3}{c}{ FYS } & N: 25 & \multicolumn{3}{c}{ SYS } & N: 25 & \multicolumn{3}{c}{ IS } & N: 5 \\
\cline { 2 - 10 } & D & NS & A & D & NS & A & D & NS & A \\
\hline 6 & $20(80)$ & $1(4)$ & $4(16)$ & $15(60)$ & $3(12)$ & $7(28)$ & $5(100)$ & $0(0)$ & $0(0)$ \\
7 & $8(12)$ & $2(8)$ & $15(60)$ & $5(20)$ & $8(32)$ & $12(48)$ & $1(20)$ & $0(0)$ & $4(80)$ \\
8 & $16(64)$ & $2(8)$ & $7(28)$ & $12(48)$ & $6(24)$ & $7(28)$ & $3(60)$ & $1(20)$ & $1(20)$ \\
9 & $13(52)$ & $2(8)$ & $10(40)$ & $15(60)$ & $5(20)$ & $5(20)$ & $4(80)$ & $0(0)$ & $1(20)$ \\
10 & $4(16)$ & $2(8)$ & $19(76)$ & $4(16)$ & $5(20)$ & $16(64)$ & $1(20)$ & $0(0)$ & $4(80)$ \\
11 & $10(40)$ & $3(12)$ & $12(48)$ & $10(40)$ & $7(28)$ & $8(32)$ & $2(40)$ & $0(0)$ & $3(60)$ \\
12 & $20(80)$ & $1(4)$ & $4(16)$ & $15(60)$ & $5(20)$ & $5(20)$ & $4(80)$ & $0(0)$ & $1(20)$ \\
\hline
\end{tabular}

Key: 6) The current syllabus items and topics are related to students' needs. 7) The current syllabus fails to achieve students' specific goals. 8) The current syllabus provides students with skills to be competent in English. 9) The current syllabus enables students to achieve medical needs. 10) The current syllabus ignores reliability and validity of ESP programs. 11) The current syllabus helps medical students by preparing them for future job needs. 12) The current syllabus lacks suitability towards students' English progress. 
In item (7), the FYS stated different responses; 20 of them answered with "Disagree" with the percentage of $80 \%$, two students responded with the statement "Not sure" with the percentage of $8 \%$ and 15 students answered with "Agree" with the percentage of $60 \%$. As for SYS, it is found that five students $20 \%$ have responded with the statement "Disagree" and eight students responded with "Not sure" with the percentage of $32 \%$ while a number of 12 students were in favor of the statement which says "The current syllabus fails to achieve students' specific goals" with ratio of $48 \%$. The same statement shows that four instructors out of five have answered with "Agree" with the percentage of $80 \%$ while one instructor disagreed that the current syllabus never fails to achieve the students' specific goals.

For the item (8), 16 students out of 25 students of FYS answered with the statement "Disagree" to clarify that the current syllabus succeeds in equipping the students with skills to be competent in English with percentage of 64\%. Two students from the same respondents answered with the statement "Not sure" amounting to the percentage of $8 \%$ while the number who responded with statement "Agree" was seven students to reach the percentage of $28 \%$. There is a difference in the responses, which received by their partners (SYS). A number of 13 students with the percentage of 52\% stated as "Disagree"; only six students amounting to the percentage of $24 \%$ responded with the statement "Not sure", but those who agreed to the item about the syllabus were seven students, giving to the percentage of $28 \%$. On the other hand, three instructors, with the percentage of $60 \%$ checked as "Disagree". The other two instructors answered with statements "Disagree" and "Agree" with the percentage of $20 \%$ for each.

In item 9, a number of 13 students of FYS (52\%) have answered with the statement "Disagree", two students responded as "Not sure" with the percentage of $8 \%$ and ten of them chose the statement "Agree" with the percentage of $40 \%$. For the SYS, a number of 15 students have rated as "Disagree" with the percentage of $60 \%$, five students of them responded with statement "Not sure" with the percentage of $20 \%$ and for the statement "Agree", the number who were in agreement to confirm that the syllabus helps students' achieving medical needs was five students, amounting to the ratio of $20 \%$. The instructors, on the other hand, their responses appeared as: only one instructor selected the statement "Agree" with the percentage (20\%) while the rest of the instructors chose the statement "Agree" with the ratio of $80 \%$.

For the item (10), there was a variation in respondents' responses. For the FYS, there was four students who replied with "Disagree" with the percentage of $8 \%$, two students checked the statement "Not sure", amounting to the percentage of $50 \%$ while the rest of same respondents (76\%) were in favor of the concept that says "the current syllabus ignores reliability and validity of ESP programs" (i.e. they agree). Their counterparts (i.e. SYS) answered for the statement "Disagree" with the percentage of $16 \%$, "Not sure" with the percentage of $20 \%$ and "Agree" with the percentage of $64 \%$. Instructors, on the other hand, their 
answers came as follows: one of them replied to the statement "Agree" with the percentage of $80 \%$. This means that most of the instructors were in favor of the concept "The current syllabus ignores reliability and validity of ESP programs". The researcher believes that attributing an answer to such question with the statement "Not sure" is unbelievable as the instructors know well what is the syllabus about and to what extent is valid for their learners (students). So, a clear-cut answer should be supported as to mean something valuable and keen to serve definite area of certain field.

The sixth item (item 11), deals with concept "The current syllabus helps medical students by preparing them for future job needs". The respondents set up different ideas about this item. For the FYS, it is found that ten students (40\%) answered with the statement "Disagree", three students (12\%) replied with statement "Not sure" while the big number of this group (48\%) chose the statement "Agree". Their partners (SYS) also brought different responses; ten students (40\%) checked for the statement "Disagree"; seven students (28\%) assigned for the statement "Not sure" since the rest of the number (32\%) checked for the statement "Agree". As for the instructors, the majority of them $(60 \%)$ chose the statement "Agree" while the rest of them (40\%) assigned "Disagree".

The last item (item 12) clarifies that a number of 20 students of FYS (80\%) chose the statement "Disagree" and for the statements "Not sure", only one student $(4 \%)$ checked it, while a number of four respondents (16\%) had given consent answer that the current syllabus lacks suitability towards students' English progress. As for SYS, it is remarked that a number of 15 students (60\%) chose the statement "Disagree"; five of the same respondents $(20 \%)$ checked as "Not sure", and the same number of students (20\%) confirmed that the current syllabus is not as good as to keep with being suitable to achieve students' English language needs while the greater part of the instructors $(80 \%)$ chose the statement of "Disagree" and (20\%) of the same respondents answered with statement "Agree". The differences in aspects yielded different considerations about the syllabus, which is in needs to be developed more often so as to suit its learners according to their area of specialization.

For the item (13) (Table 2(a)), eight students (32\%) of FYS answered with statement "Disagree"; five students belong to this group of the same respondents with the percentage of (20\%) selected the statement "Not sure" while a number of 12 students (48\%) confirmed that "The published materials rather than in-house ones are used". For the second group of students (i.e. SYS), only two students $(8 \%)$ chose the statement "Disagree"; three students from the same group selected the statement "Not sure" with the percentage of $(12 \%)$ where the majority of students (80\%) responded with the statement "Agree". In turn, four instructors chose the statement "Agree". As seen from the whole responses, the majority of the respondents selected the statement "Agree" to mean that the published materials are used for teaching the program under study. 
Table 2. (a) Analysis of the materials used; (b) Analysis of materials used (Suggestions); (c) Analysis of the effectiveness of the materials (Suggestions).

(a)

\begin{tabular}{|c|c|c|c|c|c|c|c|c|c|}
\hline \multirow{2}{*}{ Items } & \multicolumn{2}{|c|}{ FYS } & 25 & \multicolumn{2}{|c|}{ SYS } & $\mathrm{N}: 25$ & \multicolumn{2}{|c|}{ IS } & N: 5 \\
\hline & $\mathrm{D}$ & NS & A & D & NS & A & D & NS & A \\
\hline 13 & $8(32)$ & $5(20)$ & $12(48)$ & $2(8)$ & $3(12)$ & $20(80)$ & $1(20)$ & $0(0)$ & $4(80)$ \\
\hline 14 & $5(20)$ & $4(16)$ & $16(64)$ & $2(8)$ & $11(44)$ & $12(48)$ & $1(20)$ & $0(0)$ & $4(80)$ \\
\hline
\end{tabular}

Key: 13) The published materials rather than in-house ones are used. 14) The materials used by instructors are relevant to the current syllabus.

(b)

\begin{tabular}{ccccccccccc}
\hline \multirow{2}{*}{ Items } & \multicolumn{3}{c}{ FYS } & \multicolumn{2}{c}{ N: 25 } & \multicolumn{3}{c}{ SYS } & N: 25 & \multicolumn{3}{c}{ IS } & N: 5 & \\
\cline { 2 - 10 } & Yes & No & NS & Yes & No & NS & Yes & No & NS \\
\hline 15 & $15(60)$ & $5(20)$ & $5(20)$ & $15(60)$ & $6(24)$ & $4(16)$ & $4(80)$ & $1(20)$ & $0(0)$ \\
16 & $16(64)$ & $4(16)$ & $5(20)$ & $19(76)$ & $3(12)$ & $3(12)$ & $5(100)$ & $0(0)$ & $0(0)$ \\
\hline
\end{tabular}

Key: 15) Do you think the materials used in the class are more relevant to the medical situations? 16) Do you think the textbook is essential to teach the syllabus properly?

(c)

\begin{tabular}{|c|c|c|c|c|c|c|}
\hline \multirow{2}{*}{ Items } & FYS & $\mathrm{N}: 25$ & SYS & $\mathrm{N}: 25$ & IS & $\mathrm{N}: 5$ \\
\hline & A & D & A & D & A & D \\
\hline a & $15(60)$ & $5(20)$ & $20(80)$ & $3(12)$ & $4(80)$ & $1(20)$ \\
\hline $\mathrm{b}$ & $8(32)$ & $12(48)$ & $6(24)$ & $12(48)$ & $3(60)$ & $2(40)$ \\
\hline c & $12(48)$ & $8(32)$ & $15(60)$ & $6(24)$ & $2(40)$ & $3(60)$ \\
\hline $\mathrm{d}$ & $20(80)$ & $4(16)$ & $22(88)$ & $2(8)$ & $4(80)$ & $1(20)$ \\
\hline
\end{tabular}

Key: a: use more published materials such as textbooks. b: use more in-house materials prepared by instructors. c: use both published and in-house materials. d: use more technical aids such as computers, videos, and TV.

As for the item (14), it has been clarified that there is diversity of answers among the respondents. Considering the first group of the respondents (FYS), there were five students (20\%) who chose the statement "Disagree"; four students $(16 \%)$ checked for the statement "Not sure" where the greater part of this group (16 students, 64\%) presented an answer to the statement "Agree" to confirm that "The materials used by instructors are relevant to the current syllabus". As for the second group of the respondents, i.e. SYS, it is found that the majority of them (48\%) responded as "Agree"; only two students (8\%) checked as "Disagree" and the rest of them (11 students) selected the statement "Not sure" with the percentage of $(44 \%)$. Regarding the instructors, a greater number of them $(80 \%)$ agreed to the item "The materials used by instructors are relevant to the current syllabus" while there was one instructors (20\%) who answered with the statement "disagree".

From the above given responses, which concern the use of materials by the instructors to check their suitability to the current syllabus, it is found that most of 
the respondents were in agreement to the item mentioned above. Therefore, these responses provided evidence for the materials used by their instructors whether they were in-house or the published ones.

The item (15) (Table 2(b)) provided strong agreement from all the respondents FYS (60\%), SYS (60\%) and IS (80\%) to the notion of materials used by instructors, as they were relevant to the course items. Whereas in other statements, the responses assigned by the respondents were as follows: five students from $(\mathrm{FYS}=20 \%)$, six student from (SYS $=24 \%)$ and only one instructor (IS $=20 \%)$ selected the statement "No" as to disagree to the notion which contradicts with the other majority of respondents. As for the statement "Not sure", it is found that five students from FYS (20\%); four students from SYS (16\%). There were no responses received, concerning the instructors' concept about this statement.

As for the item (16), there was a general approval about the importance of the use of textbook to teach the syllabus effectively. Their agreement is provided in the form of percentage FYS (64\%), SYS (76\%) and IS (100\%). This concept represents an overall agreement from the respondents. As for the statement "No", a small number from some respondents (i.e. FYS $=16 \%$ and SYS $=12 \%$ ) who shared the answer to state that the use of a textbook is not effective to teach the syllabus. On the other hand, the statement "Not sure" has also been received a small number from respondents (FYS $=20 \%$, SYS $=12 \%$ and IS $=0 \%$ ) to mean that they were not sure whether the use of textbook necessary for the current syllabus.

The suggestions which have been drawn up by the majority of the respondents in items were as follows: the item (a) (FYS $=80 \%$, SYS $=88 \%$ and IS $=80 \%$ ) (Table 2(c)) agreed as to use more published materials (i.e. textbooks). Accordingly, the use of published materials is mostly liked by the majority of the respondents.

As for the item (b), a number of the respondents (FYS $=80 \% \%$, SYS $=76 \%$, and IS $=60 \%$ ) disagreed to the suggestion of using more in-house materials prepared by instructors as being effective for students to carry out their duties. This item of using in-house materials prepared by instructors is not preferred by the most of the respondents may be for being not well prepared or not clear.

For the item (c), only the students (FYS $=68 \%$ and SYS $=76 \%$ ) preferred the use of both published and in-house materials. So, the using of both published and in-house materials may yield better understanding for the purpose of using the materials.

The last one (item d), a great number of FYS (84\%), SYS (86\%) and IS (80\%) preferred using technical aids such as computers, videos, and TV to mean that modern technology paid a good sense and desire on respondents' trends and motivations. From my previous experience, I noticed that the use of technical aids grabbed the students' attention and helped them preparing their seminars.

\section{Conclusion}

ESP, as a significant science, has come to grow worldwide. Therefore, if the ESP 
community wishes to grow and move forward in the future, it is very important that the community as a whole understands what ESP actually stands for and to what extent they are aware of the concept of its use. Only then, can new members combine with confidence, and existing members carry on the practices which have brought ESP to the position that it has in EFL teaching today. Particularly, ESP is still in its early years and so now is the ideal time to form such a harmony. Perhaps this can stem from the Dudley-Evans' definition given in this article but I suspect a more rigorous version will be coming soon, in his book on ESP to be published in 1998. Of course, interested parties are also strongly urged to attend any predominant conference on ESP; this is certain to focus again on this topic.

\section{Conflicts of Interest}

The author declares no conflicts of interest regarding the publication of this paper.

\section{References}

Berwick, R. (1989). Needs Assessment in Language Programming: From Theory to Practice. In R. K. Johnson (Ed.), The Second Language Curriculum (pp. 48-62). Cambridge: CUP. https://doi.org/10.1017/CBO9781139524520.006

Brindley, G. (1989). The Role of Needs Analysis in Adult ESL Program Design. In R. K. Johnson (Ed.), The Second Language Curriculum (pp. 63-78). Cambridge: CUP. https://doi.org/10.1017/CBO9781139524520.007

Candlin, C. N., \& Murphy, D. (1987). Language Learning Tasks. In Lancaster Practical Papers in English Language Education (Vol. 7). Englewood Cliffs, NJ: Prentice Hall.

Celani, M. A., Holmes, J., Ramos, R. S., \& Scott, M. (1988). The Brazilian ESP Project: An Evaluation. Sao Paulo.

Dudley-Evans, T., \& St. John, M. J. (1998). Developments in English for Specific Purposes: A Multi-Disciplinary Approach. Cambridge, UK: Cambridge University Press.

Flowerdew, J., \& Peacock, M. (2001). Research Perspectives on English for Academic Purposes. Cambridge: CUP. https://doi.org/10.1017/CBO9781139524766

Fried-Booth, D. L. (1986). Project Work. Oxford, England: Oxford University Press.

Graves, K. (1996). Teachers as Course Developers. Cambridge, England: Cambridge University Press. https://doi.org/10.1017/CBO9780511551178

Horowitz, D. M. (1986). What Professors Actually Require: Academic Tasks for the ESL Classroom. TESOL Quarterly, 20, 61-78. https://doi.org/10.2307/3586294

Hutchinson, T., \& Waters, A. (1993). English for Specific Purposes. Cambridge: Cambridge University Press.

Hutchinson, T., \& Waters, A. (1987). English for Specific Purposes: A Learner-Centered Approach. Cambridge: Cambridge University Press.

https://doi.org/10.1017/CBO9780511733031

Johns, A. M. (1991). English for Specific Purposes (ESP): Its History and Contributions. In M. Celce-Murcia (Ed.), Teaching English as a Second or Foreign Language (pp. 67-77). Boston, MA: Heinle \& Heinle.

Johns, T. F. (1981). Some Problems of a Worldwide Profession' in ELT Documents 112: The ESP Teacher: Role, Development and Prospects. British Council. 
Jordan, R. R. (1997). English for Academic Purposes: A Guide and Resource Book for Teachers. Cambridge, UK: Cambridge University Press. https://doi.org/10.1017/CBO9780511733062

Kachru, B. B. (1986). The Alchemy of English: The Spread Functions and Models of Non-Native Englishes. Oxford: Pergamon.

Kennedy, C., \& Bolitho, R. (1990). English for Specific Purposes. London: Macmillan Publishers Ltd.

Knox, A. B. (1986). Helping Adults Learn. San Francisco, CA: Jossey-Bass.

Long, M. (2005). Methodological Issues in Learner Needs Analysis. In M. H. Long (Ed.), Second Language Needs Analysis (pp. 19-76). Cambridge: Cambridge University Press. https://doi.org/10.1017/CBO9780511667299.002

Lytle, S. L. (1988). From the Inside Out: Reinventing Assessment. Focus on Basics, 2, 1-4.

Munby, J. (1978). Communicative Syllabus Design. Cambridge University Press: Cambridge.

Ostler, S. E. (1980). A Survey of Academic Needs for Advanced ESL. TESOL Quarterly, 14, 489-502. https://doi.org/10.2307/3586237

Richterich, R. (1983). Case Studies in Identifying the Needs. Oxford: Pergamon Press.

Richterich, R., \& Chancerel, J. L. (1980). Identifying the Needs of Adults Learning a Foreign Language. Oxford: Pergamon.

Richterich, R., \& Chancerel, J. L. (1987). Identifying the Needs of Adults Learning a Foreign Language. Strasbourg: Council of Europe.

Robinson, P. C. (1991). ESP Today: A Practitioner's Guide. London: Prentice-Hall International.

Schleppegrell, M. J., \& Royster, L. (1990). Business English: An International Survey. English for Specific Purposes , 9, 3-16. https://doi.org/10.1016/0889-4906(90)90025-8

Sharp, A. (1990). Staff/Student Participation in Course Evaluation: A Procedure for Improving Course Design. ELT Journal, 44, 132-137. https://doi.org/10.1093/elt/44.2.132

Styler, W. E. (1986). Adult Education in the Sudan. African Affairs, 56, 289-294. https://doi.org/10.1093/oxfordjournals.afraf.a094508

West, R. (1994). Needs analysis in Language Teaching. Language Teaching, 27, 1-19. https://doi.org/10.1017/S0261444800007527

White, R. V. (1988). The ELT Curriculum: Design, Innovation and Management. Oxford: Basil Blackwell.

Wright, C. (1992). The Benefits of ESP. Cambridge Language Consultations. http://camlang.com/art001.htm

Yalden, J. (1984). Syllabus Design in General Education. In C. J. Brumfit (Ed.), General English Syllabus Design. New York: Pergamon.

Yoo, K. F. (2000). An Evaluation of an ESP Course at a Polytechnic in Malaysia. Dissertation. Faculty of Languages and Linguistics.

\section{Websites}

http://www.esp-world.info/Articles_10/issue_10.htm

http://iteslj.org/Articles/Gatehouse-ESP.html 